\title{
Aphid endosymbiont facilitates virus transmission by modulating the volatile profile of host plants
}

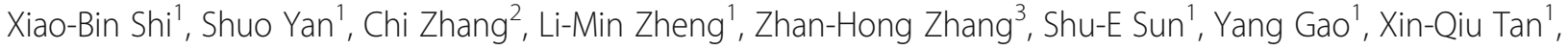 \\ De-Yong Zhang ${ }^{1 *}$ and Xu-Guo Zhou ${ }^{2^{*}}$ (i)
}

\begin{abstract}
Background: Most plant viruses rely on vectors for their transmission and spread. One of the outstanding biological questions concerning the vector-pathogen-symbiont multi-trophic interactions is the potential involvement of vector symbionts in the virus transmission process. Here, we used a multi-factorial system containing a non-persistent plant virus, cucumber mosaic virus (CMV), its primary vector, green peach aphid, Myzus persicae, and the obligate endosymbiont, Buchnera aphidicola to explore this uncharted territory.

Results: Based on our preliminary research, we hypothesized that aphid endosymbiont B. aphidicola can facilitate CMV transmission by modulating plant volatile profiles. Gene expression analyses demonstrated that CMV infection reduced $B$. aphidicola abundance in $M$. persicae, in which lower abundance of $B$. aphidicola was associated with a preference shift in aphids from infected to healthy plants. Volatile profile analyses confirmed that feeding by aphids with lower B. aphidicola titers reduced the production of attractants, while increased the emission of deterrents. As a result, $M$. persicae changed their feeding preference from infected to healthy plants.

Conclusions: We conclude that CMV infection reduces the B. aphidicola abundance in M. persicae. When viruliferous aphids feed on host plants, dynamic changes in obligate symbionts lead to a shift in plant volatiles from attraction to avoidance, thereby switching insect vector's feeding preference from infected to healthy plants.
\end{abstract}

Keywords: Myzus persicae, Buchnera aphidicola, Cucumber mosaic virus, Plant volatile, Multi-trophic interaction

\section{Background}

Most of plant viruses are transmitted by arthropod vectors such as whiteflies and aphids. Plant viruses can directly or indirectly influence vector physiology and behavior to facilitate their transmission [1]. Viruses can also alter plant volatiles to recruit insect vectors for efficient transmission $[2,3]$. To understand the mechanisms governing the virus

\footnotetext{
*Correspondence: dyzhang78@163.com; xuguozhou@uky.edu

${ }^{1}$ Laboratory of Pest Management of Horticultural Crop of Hunan Province, Hunan Plant Protection Institute, Hunan Academy of Agricultural Sciences, Changsha 410125, China

${ }^{2}$ Department of Entomology, University of Kentucky, Lexington, KY 40546, USA

Full list of author information is available at the end of the article
}

transmission is important to reveal the plant-virus-vector co-evolution, and provide a basis for manipulating vectors to limit virus spread in plants [4].

Cucumber mosaic virus (CMV), genus Cucumovirus, family Bromoviridae, is one of the ten most devastating plant viruses $[5,6]$. CMV can infect a broad range of hosts, including vegetables and ornamentals. CMV is vectored by over 80 aphid species in a nonpersistent manner. Among those, Myzus persicae is the most extensively studied vector [7]. CMV-infected plants release a greater quantity of volatiles than healthy plants, and aphids were attracted to infected plants [8]. CMV infection can trigger antibiosis

(c) The Author(s). 2021 Open Access This article is licensed under a Creative Commons Attribution 4.0 International License, which permits use, sharing, adaptation, distribution and reproduction in any medium or format, as long as you give appropriate credit to the original author(s) and the source, provide a link to the Creative Commons licence, and indicate if changes were made. The images or other third party material in this article are included in the article's Creative Commons licence, unless indicated otherwise in a credit line to the material. If material is not included in the article's Creative Commons licence and your intended use is not permitted by statutory regulation or exceeds the permitted use, you will need to obtain permission directly from the copyright holder. To view a copy of this licence, visit http://creativecommons.org/licenses/by/4.0/ The Creative Commons Public Domain Dedication waiver (http://creativecommons.org/publicdomain/zero/1.0/) applies to the data made available in this article, unless otherwise stated in a credit line to the data. 
against aphids, leading to rapid aphid dispersal after virus acquisition [9].

Buchnera aphidicola, a primary symbiotic bacterium, provides essential amino acids for aphids. In turn, aphids offer $B$. aphidicola with nitrogenous substrates, including non-essential amino acids for the endosymbiont to produce essential amino acids [10]. It has been hypothesized that endosymbionts of insects contribute to the transmission of certain luteovirids and geminiviruses [11-13], although the evidences are debatable [14] . Nevertheless, the consensus is that additional research is needed to demonstrate the direct and/or indirect involvement/effect of endosymbionts in the transmission of plant virus in different vectorvirus systems [12]. Up to now, the role of $B$. aphidicola in the transmission of non-persistent virus such as CMV is largely unclear.

During insect feeding, endosymbionts can alter the quantity and quality of plant volatiles to affect their insect hosts [15]. Moreover, plant can directly target endosymbionts to control behavior of its insect host. Recently, Chaudhary et al. demonstrated that during feeding, B. aphidicola in aphid saliva induced plant defense, which, in turn, reduced aphid fecundity [16]. Such interactions among aphid-endosymbiont-plant may indirectly influence virus transmission via modulation of plant networks [12]. However, limited information is currently available regarding whether aphid endosymbiont is involved in the non-persistent plant virus transmission. Our previous results demonstrated that CMV infection enhanced plant defense and reduced aphid fecundity [17]. Previously, we found that infection by CMV can shift feeding preference of its insect vector, $M$. persicae, from infected to healthy plants. Building on the preliminary research, we hypothesized that aphid endosymbiont $B$. aphidicola may affect herbivore behaviors through modulating plant volatile profiles.

To examine this hypothesis, we carried out the following objectives to investigate the 1) host preferences of viruliferous aphids between infected and healthy plants; 2) B. aphidicola abundance in CMV-infected and rifampicin-treated $M$. persicae, respectively; 3) volatile profiles of CMV-infected and non-infected host plants non-infested or infested by healthy, CMV-infected and rifampicin-treated M. persicae; and 4) functions of the resultant volatiles from Objective-3.

\section{Results}

Host preference of aphids between infected and healthy plants

The number of $M$. persicae on CMV-infected plants was significantly lower than that on healthy plants $\left(\mathrm{F}_{1,16}=4.975, P<0.001\right.$, Fig. $\left.1 \mathrm{a}\right)$, while the number of non-viruliferous $M$. persicae on CMV-infected plants was significantly higher than that on healthy plants $\left(\mathrm{F}_{1},{ }_{16}=2.602, \quad P=0.005\right.$, Fig. $\left.1 \mathrm{~b}\right)$, suggesting that CMV-infected aphids preferred healthy plants.

\section{Buchnera aphidicola abundance among CMV-infected and rifampicin-treated aphids}

Buchnera aphidicola sequence, 1845-bp in length, shared $99.9 \%$ similarity to the B. aphidicola sequence from $M$. persicae genome (Accession number: CP002703, 275,749-276,779 site of B. aphidicola genome).

CMV infection significantly reduced the abundance of $B$. aphidicola, and the Buchnera abundance was significantly lower in CMV-infected aphids than in the control aphids $\left(F_{1,4}=2.474, P<0.001\right)$. Similarly, $B$. aphidicola was also significantly reduced after rifampicin treatment $\left(\mathrm{F}_{4}, 14=71.708, P<0.001\right)$, in a dose-dependent manner. In comparison to the controls, $B$. aphidicola abundance in $M$. persicae treated with $200 \mu \mathrm{g} / \mathrm{mL}$ rifampicin was reduced by $>2$-fold (Fig. 2).
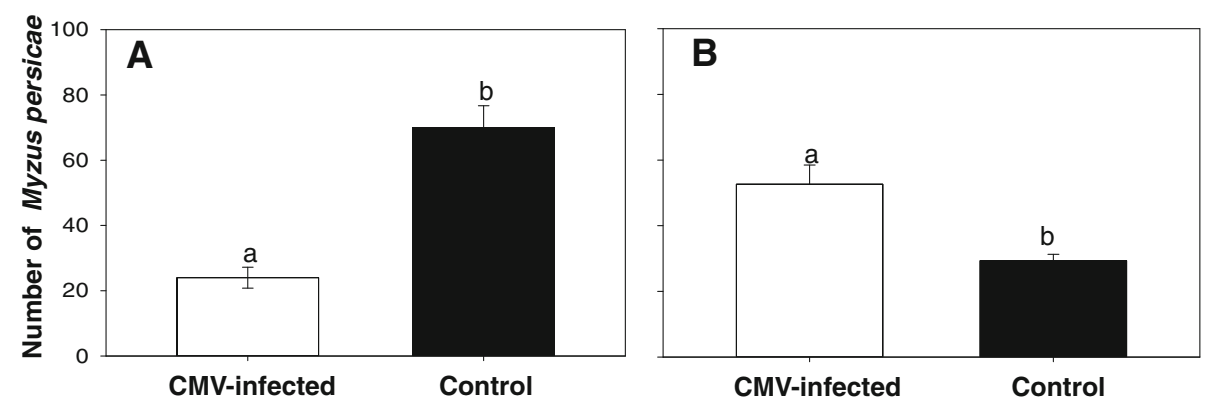

Fig. 1 Preference of aphids between infected and healthy plants. a. CMV-infected aphids. b. non-infected aphids. Values are means \pm SE. Different letters indicate significant differences $(p<0.05)$ by t-test 


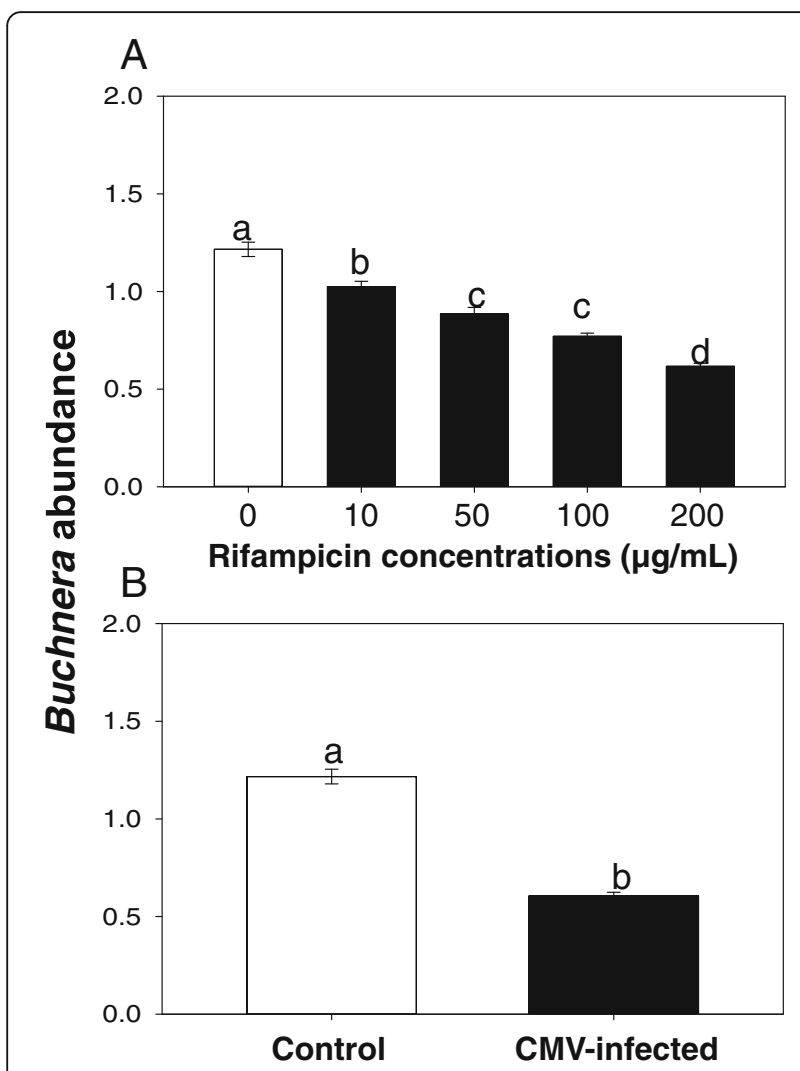

Fig. 2 Buchnera aphidicola abundance of rifampicin-treated aphids. The index of $B$. aphidicola abundance, ratio of amplicons of $B$. aphidicola Buch gene/EF1 a gene was determined. Values are means \pm SE. Different letters indicate significant differences $(p<0.05)$ by ANOVA and Tukey's HSD post hoc test
Plant volatile profiles on plants infested by $M$. persicae with reduced $B$. aphidicola abundance

The volatile profiles were similar qualitatively, however, different quantitatively. Compared with healthy plants, healthy plants infested with healthy aphids released the significant higher titers of $\alpha$-pinene, $\gamma$ - terpinene; healthy plants infested with rifampicin-treated aphids released the significant higher titers of $\alpha$-pinene, $\gamma$ - terpinene, $\sigma$ cymene, and 2-octanol, while significant lower titers of benzyl alcohol and $\sigma$-xylene; $C M V$-infected plants significantly increased the titers of benzyl alcohol and $\sigma$ xylene, while significantly reduced the titers of $\sigma$-cymene and 2-octanol; CMV-infected plants infested with healthy aphids and CMV-infected plants infested with rifampicin-treated aphids both significantly increased the titers of $\alpha$-pinene, $\beta$-pinene, $\gamma$ - terpinene, $\sigma$-cymene and 2-octanol, while reduced the titers of benzyl alcohol and $\sigma$-xylene, significantly (Fig. 3 ).

\section{Function analysis of the resultant volatiles}

In Y-tube analysis, healthy, CMV-infected, and rifampicin-treated $M$. persicae were significantly repelled by 2 -octanol, o-cymene, $\alpha$-pinene, $\beta$-pinene, and $\gamma$ terpinene, while significantly attracted by benzyl alcohol and $\sigma$-xylene. As for 3-hexen-1-ol, 1-butanol, and nhexanal, the healthy, CMV-infected, and rifampicintreated M. persicae did not show any preference (Fig. 4).

\section{Discussion}

Plant virus can influence the host selection behavior of its insect vector to facilitate the virus transmission $[18,19]$, such as the increased alate production in infected aphid vectors [17, 20]. Recently, the multitrophic interactions among plant pathogens, insect vectors and plant hosts have expanded to involve a fourth party: bacterial symbionts harbored within the insect vector [12].

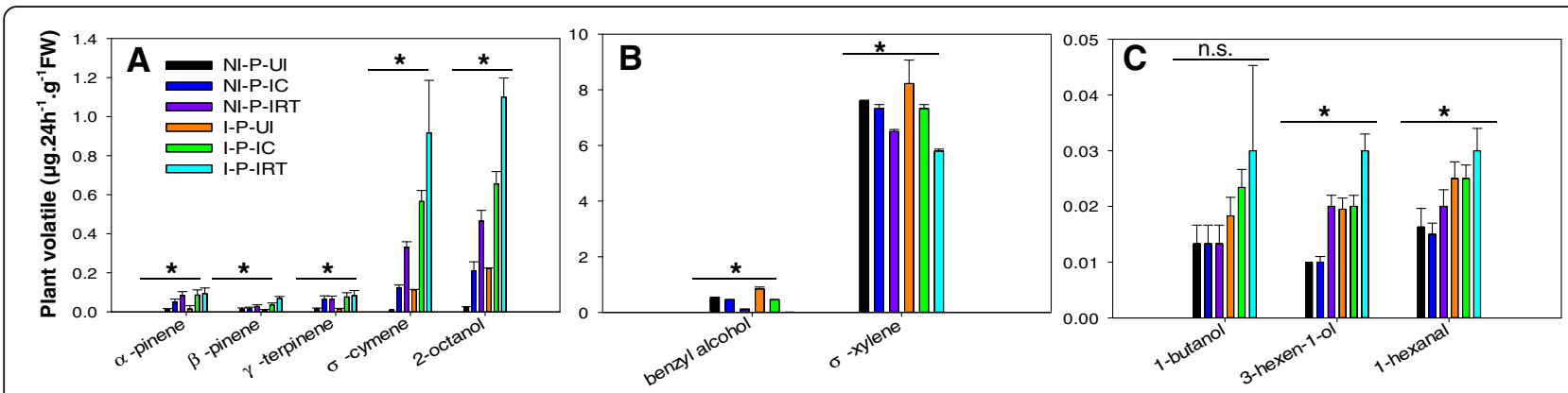

Fig. 3 Content of plant volatiles in different treatment. NI-P-UI: non-infected control plants; NI-P-IC: non-infected plants infested by healthy aphids; NI-P-IRT: non-infected plants infested by rifampicin-treated aphids; I-P-UI: CMV-infected plants; I-P-IC: CMV-infected plants infested by healthy aphids; I-P-IRT: CMV-infected plants infested by rifampicin-treated aphids. a. Plant volatiles of a-pinene, $\beta$-pinene, $\gamma$-terpinene, $\sigma$-cymene, and 2-octanol, on plants in different treatments. b. Plant volatiles of benzyl alcohol and $\sigma$-xylene, on plants in different treatments. c. Plant volatiles of 1-butanol, 3-hexen-1-ol, and 1-hexanal, on plants in different treatments. Values are means $\pm \mathrm{SE}$. Asterisks indicate significant differences $(p<0.05)$ by ANOVA and Tukey's HSD post hoc test 


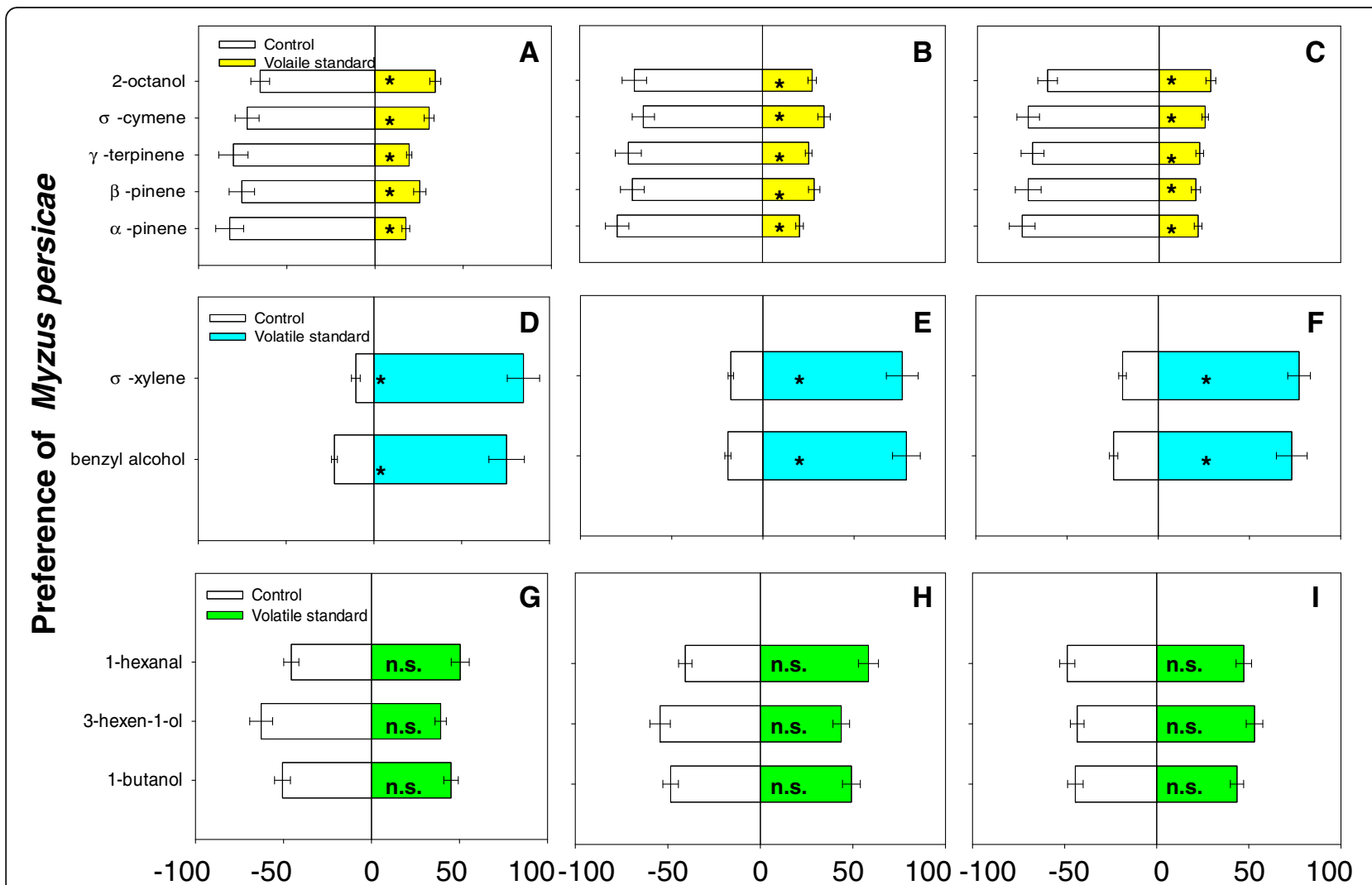

Fig. 4 Aphid preference affected by volatiles. a. Healthy aphids' preference. b. CMV-infected aphids' preference. c. Rifampicin-treated aphids' preference. $\mathbf{d}$. Healthy aphids' preference. e. CMV-infected aphids' preference. f. Rifampicin-treated aphids' preference. g. Healthy aphids' preference. $\mathbf{h}$. CMV-infected aphids' preference. i. Rifampicin-treated aphids' preference. Values are means \pm SE. Asterisks indicate significant differences $(P<0.05)$ between volatile standard and control by a general linear model. n.s. indicates not significant between volatile standard and control

\section{Shift in feeding preference of CMV-infected aphids facilitates the virus transmission}

It is expected that most plant viruses can induce changes in plants that have positive effects for transmission by insect vectors [21]. Here, CMVinfected aphids were attracted to the healthy plants rather than CMV-infected plants, and previous research on Aphis gossypii alates also showed the shift preference from CMV-infected to mock-inoculated plants [22]. Besides, when aphids were exposed to CMV-infected plants, the probing behavior showed a sharp change over time [22]. The increased number of CMV-infected aphids on healthy plants, in theory, will facilitate virus transmission in the field. However, the mechanism of aphid shifted preference mediated by non-persistent plant virus is largely unknown.

\section{CMV infection reduced the relative abundance of $B$. aphidicola in M. persicae}

Our RT-qPCR analysis showed that CMV infection reduced the relative abundance of $B$. aphidicola in $M$. persicae. In a parallel experiment, rifampicin treatment, not surprisingly, significantly reduced the $B$. aphidicola titer in $M$. persicae, which is consistent with previous findings [23]. Although bacterial endosymbionts in $M$. persicae could be abundant and diverse, we only detected B. aphidicola following [24]. None of the other symbionts, such as Rickettsia, Hamiltonella, Wolbachia, and Spiroplasma, were detected in this study. Interestingly, however, the level of reduction in B. aphidicola abundance in M. persicae infected with CMV was comparable to the aphids treated with the highest concentration of antibiotics $(200 \mu \mathrm{g} / \mathrm{mL}$ rifampicin; Fig. 2). Nevertheless, the eventual choice by aphids ultimately favor the transmission and spread of virus, an apparent incentive for virus during the co-evolution with its insect vector.

\section{Reduced B. aphidicola titer in aphids leads to the quantitative changes in plant volatiles}

Plants often respond to herbivore attack by releasing a specific blend of volatiles [25]. Previous research showed that the volatiles emitted by CMV-infected plants 
appeared to be qualitatively similar to the blend emitted by healthy plants [8], which is in consistent with our results. Some terpenes typically repel arthropod herbivores, such as $\sigma$-cymene, $\alpha$-pinene, $\beta$-pinene, and $\gamma$ terpinene [26-29], which is consistent with our results. $\sigma$-xylene, however, attracts aphids in our study, but deters whiteflies, Bemisia tabaci (Gennadius) [30]. The discrepancy might depend on insect species. Mauck et al. (2010) showed that aphids were attracted to CMVinfected plants at first, and the viruliferous aphids emigrated from infected plants at a higher rate and exhibited reduced population growth when forced to feed on infected plants, suggesting that reductions in host palatability lead to the rapid dispersal of CMV-infected aphids [31]. Here we found that CMV-infected plants released higher titer of attractive plant volatile, while after CMV-infected plants were infested by healthy aphids and $B$. aphidicola-decreased aphids, the repellent volatile was induced and the attractive volatiles were reduced, and the phenomena may also explain the rapid dispersal of CMV-infected aphids. The result might vary in field conditions. This effect may be indirect, because the higher attractivity of healthy plants could be likely induced just to limit the insect infection by viruses, since the viruliferous status hampers the aphid life cycle. For this reason, these aphids could be attracted by healthy plants just to escape further virus infection, and this may indirectly induce actual transmission.

The mutualism between aphid, $M$. persicae, and its primary symbiont, $B$. aphidicola, is obligate, in which the partners cannot survive without the other. By reducing the abundance of $B$. aphidicola, the overall fitness of $M$. persicae is compromised. CMV is exploiting the situation by presenting a choice to its insect vector between the immunocompromised (infected) and nutritionally intact (healthy) host plants. In the meantime, the reduced $B$. aphidicola abundance quantitatively changes the plant volatile profiles to orient a choice by the insect vector favoring the transmission and spread of virus (Fig. 5).

During the transmission process of plant virus by insect vectors in a non-persistent manner, plant viruses are believed to be retained in the insect stylet. The debate in this field is that whether insect endosymbionts are involved in the process of non-persistent virus transmission. Based on this study, we proposed a simple model for B. aphidicola in the role of CMV transmission. This model exemplified the dynamics of aphids' preference shift from CMV-infected plants to noninfected plants. The B. aphidicola abundance decrease in viruliferous aphids affected the plant volatile profiles, which result in the aphid preference shift from infected to healthy plants, and finally leads to the CMV outbreak (Fig. 5).

\section{Conclusion and perspectives}

Up to date, most attentions have been given to how insect endosymbionts regulate circulative virus transmission, and results show that $B$. aphidicola can protect luteovirids from degradation in the aphid hemolymph during virus transmission [32]. In this study, we found that $B$. aphidicola also contributes to the transmission of a non-persistent plant virus, in a different manner.

This is one of the first studies to empirically examine how endosymbionts of CMV-infected aphids impact dynamics of plant volatiles to manipulate aphid preference and CMV transmission. We testified that the symbiont is involved in non-persistent virus transmission. We conclude that the decrease of $B$. aphidicola abundance in CMV-infected aphids reduced the quantity of attractive volatile and increased the quantity of reject volatile to indirectly cause the dispersal of CMV-infected aphids. Endosymbiont-mediated volatile change will drive the viruliferous aphids to healthy plants, thus providing more opportunity for viruliferous aphids to transmit virus, which might be essential for CMV to evolve and adapt to a vector-borne lifestyle.

\section{Methods}

\section{Host plant, aphid colonies and CMV culture}

The green peach aphid, Myzus persicae (Sulzer), was a gift from Dr. Xiwu Gao of China Agricultural University and has been maintaining on the pepper plant, Capsicum annuum L., (Zhongjiao 5, Chinese Academy of Agricultural Sciences). The formal identification of the samples used in this study was performed by Xiao-Bin Shi. Voucher specimens were deposited in the herbarium of Hunan Plant Protection Institute. CMV-AN isolate (subgroup IB, stored at $-80^{\circ} \mathrm{C}$ in Nicotiana glutinosa) was inoculated into pepper plants at the $4-5$ true leaf stage [17]. Healthy pepper with the same developmental stage was used as the controls. After 9 days, virus infection was confirmed by double-sandwich enzyme-linked immunosorbent assay (DAS-ELISA) [17]. CMV-infected aphids were generated by allowing $M$. persicae to feed on CMV-infected plants for $5 \mathrm{~min}$ [33].

\section{Host preference of aphids between infected and healthy plants}

The CMV-infected aphids and non-infected aphids were used in the preference test. The CMV-infected and healthy pepper plants were placed in two separate collection pots. The two arms of Y-tube olfactometer were connected to the two corresponding pots via vacuum lines. Individual aphids were released at the base of the Y-tube. Each aphid was observed no more than $20 \mathrm{~min}$. A choice was recorded when the aphid moved $>10 \mathrm{~cm}$ onto either arm and stayed in that arm for at least 5 min, and a 'no choice' was recorded when the aphids 


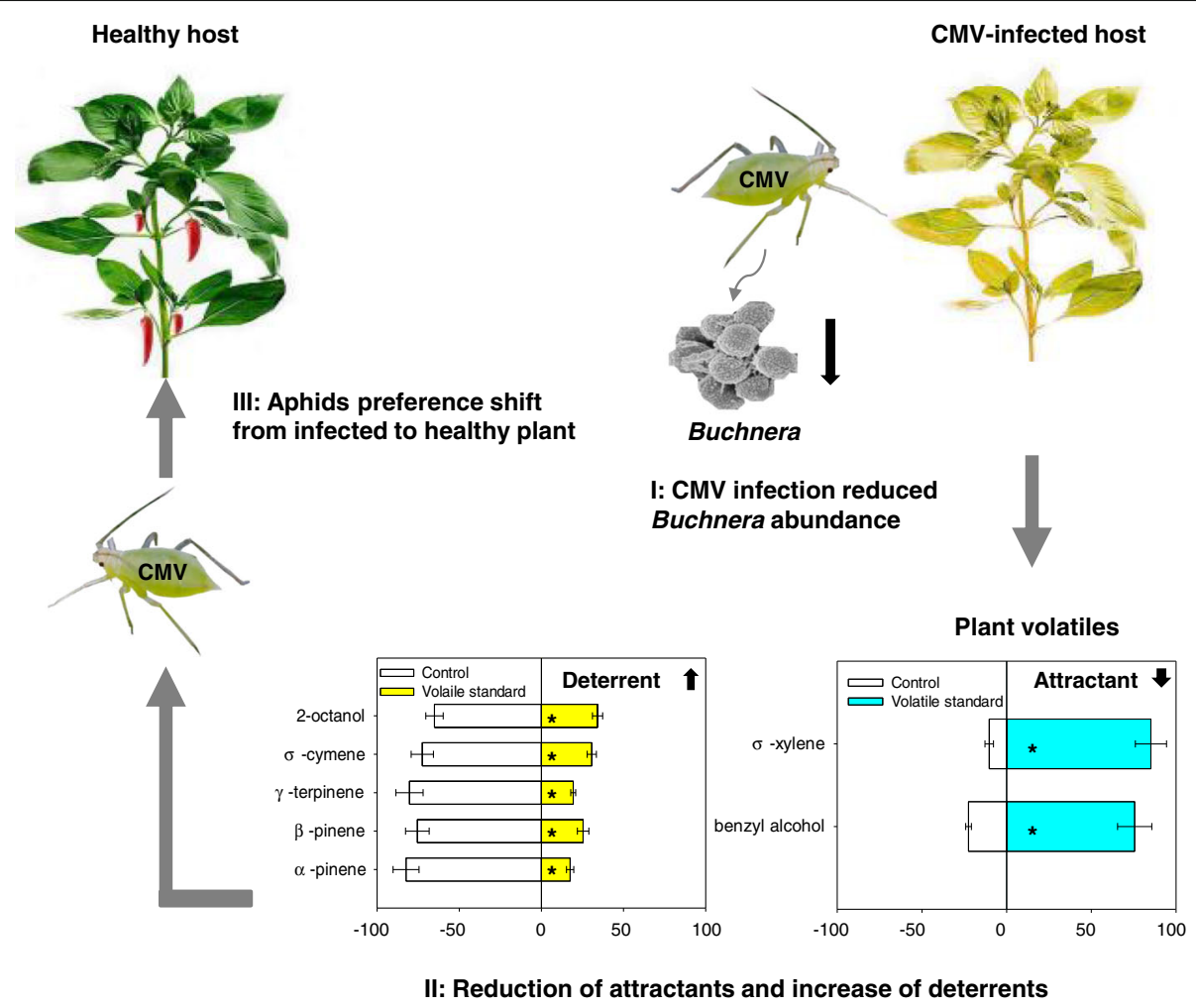

Fig. 5 Proposed model for CMV outbreak facilitated by B. aphidicola-mediated shift in CMV-infected aphid's feeding preference. Stage I: CMVinfected aphids prefer to feed on the healthy plants. Stage II: After feeding, the host plants are infected, and B. aphidicola abundance in CMVinfected aphids decreases. Stage III: After infection, the dynamics of plant volatile profiles is changed, with less attractants and more repellents. As a result, the feeding preference of aphid shifts from infected to healthy plants. Stage IV: Dispersal of CMV-infected aphids leads to CMV outbreak

were remained inactive during the testing period. After five aphids were tested, odor sources were switched to avoid any unpredictable asymmetry of the setup. A total number of $90 \mathrm{CMV}$-infected and non-infected aphids were tested for 3 times per day and for 3 days. The inner and outer arms of the Y-tube were carefully wiped with 95\% ethanol and dried each day.

The establishment of rifampicin-treated $M$. persicae, and quantification of Buchnera aphidicola in aphids

The rifampicin-treated $M$. persicae was established by maintaining aphids on artificial diets supplemented with rifampicin at concentrations of $10,50,100$, and $200 \mu \mathrm{g} /$ $\mathrm{mL}$ for $48 \mathrm{~h}[23,34]$. The control aphids were maintained on regular artificial diets for $48 \mathrm{~h}$. After $48 \mathrm{~h}, B$. aphidicola abundance was determined.

The genomic DNA of Myzus persicae was extracted with Chelex (Sigma-Aldrich, St Louis, MO, USA) following a protocol described previously [35]. Here, polymerase chain reaction (PCR)-based diagnostic tools were used to identify the endosymbionts in M. persicae, including B. aphidicola, Rickettsia, Hamiltonella defensa, Wolbachia, and Spiroplasma (Table 1). The resultant PCR products were cloned, sequenced, and confirmed using BLAST. Only the $1845 \mathrm{bp}$ region of $B$. aphidicola was amplified and confirmed. The abundance of $B$. aphidicola in viruliferous and control aphids was estimated by the ratio of $B$. aphidicola amplicons of Buch (forward primer: AGCGGCCTCCTAAACGAAAA; reverse primer: AGTCGACATCGTTTACGGCA)/EF1 $\alpha$ (forward primer: AGAATGGACAAACCCGTGAA; reverse primer: CACTGTATGGTGGTTCAGTAGAG) using RTqPCR [36, 37]. For RT-qPCR analysis, three biological replicates were carried out for each experiment. For each biological replicate, four technical replicates were included. The relative expression of Buch, the target gene, was normalized to $E F 1 \alpha$, the internal reference, using 2 $-\Delta \Delta \mathrm{CT}$ method [38].

\section{Plant volatile analysis}

A headspace system (Shi et al., 2018) was used to collect volatiles, including healthy plants, healthy plants infested with control aphids, healthy plants infested with rifampicin-treated $(200 \mu \mathrm{g} / \mathrm{mL})$ aphids, CMV-infected plants, CMV-infected plants with control aphids, and CMV-infected plants infested with rifampicin-treated $(200 \mu \mathrm{g} / \mathrm{mL})$ aphids. Plant volatile of all the treatments were collected for $6 \mathrm{~h}$, and 
Table 1 Diagnostic primers used for the detection of endosymbionts in M. persicae

\begin{tabular}{|c|c|}
\hline Endosymbiont & Primer sequence $\left(5^{\prime}-3^{\prime}\right)^{a}$ \\
\hline Buchnera aphidicola & $\begin{array}{l}\text { F: CATGGCTCAGATTCAACGCTGGCG } \\
\text { R: CCCCTCGGTTACCTTCTTACGAC }\end{array}$ \\
\hline Wolbachia & $\begin{array}{l}\text { F: AGAGTTTGATCATGGCTCAGATTG } \\
\text { R: TACCTTGTTACGACTTCACCCCAG }\end{array}$ \\
\hline Rickettsia & $\begin{array}{l}\text { F: AGAGTTTGATCMTGGCTCAG } \\
\text { R: CATCCATCAGCGATAAATCTITC }\end{array}$ \\
\hline Hamiltonella defensa & $\begin{array}{l}\text { F: AGCACAGTTAACTGAGTTCA } \\
\text { R: TACGGYTACCTTGTTACGACTT }\end{array}$ \\
\hline Spiroplasma & $\begin{array}{l}\text { F: AGAGTTTGATCMTGGCTCAG } \\
\text { R: TAGCCGTGGCTITCTGGTAA }\end{array}$ \\
\hline
\end{tabular}

"an": Forward and Reverse primers

aphid infestation was maintained in $6 \mathrm{~h}$ with clipcages, and non-infestation plants were also treated with clip-cages. For each treatment, volatile collection was independently replicated three times, including three technical replicates for each biological replicate.

\section{Functional analysis of host plant volatiles}

The response of healthy, CMV-infected, and rifampicintreated $M$. persicae to the 10 detected volatiles was determined using a Y-tube olfactometer. The standards of 3hexen-1-ol, 1-butanol, n-hexanal, benzyl alcohol, $\sigma$-xylene, 2 -octanol, o-cymene, $\alpha$-pinene, $\beta$-pinene and $\gamma$-terpinene were inlcuded in the Y-tube test. Two streams of purified air (filtered through activated charcoal) were led through two glass containers (a standard chemical and a purified air as the control) into the two arms of Y-tube olfactometer at $100 \mathrm{~mL} / \mathrm{min}$. The aphid preference was test according to the method described in the section of "Host preference of viruliferous aphids between infected and healthy plants". For each treatment, a group of 90 healthy, CMV-infected, and rifampicin-treated aphids were tested for 3 times per day, for 3 days. A total of 2700 aphids were used to examine the function of the 10 resultant volatiles.

\section{Statistical analysis}

SPSS version 20.0 (SPSS Inc., Chicago, IL, USA) was used for all statistical analyses. One sample t-test was used to compare the preference of CMV-infected aphids and to compare the B. aphidicola amplicons of Buch /EF1 $\alpha$ in CMV-infected and control aphids. One-way ANOVA was used to compare the B. aphidicola amplicons of Buch $/ E F 1 \alpha$ in rifampicin-treated aphids at concentrations of 0 , $10,50,100$, and $200 \mu \mathrm{g} / \mathrm{mL}$. The volatiles released on plants in different treatments were also compared with one-way ANOVA. Effects of the 10 detected plant volatiles on preference of healthy, CMV-infected, and rifampicin-treated aphids in Y-tube olfactometer were compared with General linear model (GLM).

\section{Abbreviations}

CMV: Cucumber mosaic virus; AGO1: ARGONAUTE1; DAS-ELISA: Doublesandwich enzyme-linked immunosorbent assay

\section{Acknowledgements}

Authors are grateful to anonymous reviewers for their constructive comments and suggestions.

\section{Authors' contributions}

$X B S, D Y Z$ and XGZ conceived the research and contributed ideas. XBS, SY and $Y G$ conducted experiments, SY, ZHZ, SES, LMZ, XQT, and XGZ analyzed the data. XBS, CZ and XGZ wrote the manuscript. All authors read and approved the manuscript.

\section{Funding}

This work was supported by the Hunan Natural Science Foundation (2019JJ30014), the Agriculture Research System of China (CARS-16-E-17, CARS-23-D-02), the National Natural Science Foundation of China (no. $32030088,32072383,31872932,31901854)$. The funders had no role in the design of the study; in the collection, analyses, or in the preparation of data; in the writing of the manuscript, or in the decision to publish the results.

\section{Availability of data and materials}

The datasets used and/or analyzed during the current study are available from the corresponding author on reasonable request.

Ethics approval and consent to participate

Not applicable.

\section{Consent for publication}

Not applicable.

\section{Competing interests}

The authors declare that they have no competing interests.

\section{Author details}

${ }^{1}$ Laboratory of Pest Management of Horticultural Crop of Hunan Province, Hunan Plant Protection Institute, Hunan Academy of Agricultural Sciences, Changsha 410125, China. ${ }^{2}$ Department of Entomology, University of Kentucky, Lexington, KY 40546, USA. ${ }^{3}$ Institute of Vegetable, Hunan Academy of Agricultural Sciences, Changsha 410125, China.

Received: 11 November 2020 Accepted: 11 January 2021

Published online: 29 January 2021

\section{References}

1. Gutiérrez S, Michalakis Y, Van Munster M, Blanc S, Biere A. Plant feeding by insect vectors can affect life cycle, population genetics and evolution of plant viruses. Funct Ecol. 2013;27(3):610-22.

2. Shi X, Chen G, Pan H, Xie W, Wu Q, Wang S, et al. Plants pre-infested with viruliferous MED/Q cryptic species promotes subsequent Bemisia tabaci infestation. Front Microbiol. 2018;9:1404.

3. Shi X, Preisser EL, Liu B, Pan H, Xiang M, Xie W, et al. Variation in both host defense and prior herbivory can alter plant-vector-virus interactions. BMC Plant Biol. 2019;19(1):556

4. Jeger M, Fereres A, Mauck K, Wintermantel W. Reducing the spread of plant viruses through communication and global cooperation. Virus Res. 2020;288: 198139.

5. Scholthof KBG, Adkins S, Czosnek H, Palukaitis P, Jacquot E, Hohn T, et al. Top 10 plant viruses in molecular plant pathology. Mol Plant Pathol. 2011; 12(9):938-54.

6. Mochizuki T, Ohki S. Cucumber mosaic virus: viral genes as virulence determinants. Mol Plant Pathol. 2012;13(3):217-25.

7. Jacquemond M. Cucumber mosaic virus. In: Advances in virus research, vol. 84: Elsevier; 2012. p. 439-504.

8. Mauck KE, De Moraes CM, Mescher MC. Deceptive chemical signals induced by a plant virus attract insect vectors to inferior hosts. Proc Natl Acad Sci. 2010;107(8):3600-5.

9. Westwood JH, Groen SC, Du Z, Murphy AM, Anggoro DT, Tungadi T, et al. A trio of viral proteins tunes aphid-plant interactions in Arabidopsis thaliana. PLoS One. 2013;8(12):1. 
10. Zhang Y, Su X, Harris AJ, Caraballo-Ortiz MA, Ren Z, Zhong Y. Genetic structure of the bacterial endosymbiont Buchnera aphidicola from its host aphid Schlechtendalia chinensis and evolutionary implications. Curr Microbiol. 2018;75(3):309-15.

11. Cassone BJ, Redinbaugh MG, Dorrance AE, Michel AP. Shifts in Buchnera aphidicola density in soybean aphids (aphis glycines) feeding on virusinfected soybean. Insect Mol Biol. 2015;24(4):422-31.

12. Pinheiro PV, Kliot $A$, Ghanim M, Cilia M. Is there a role for symbiotic bacteria in plant virus transmission by insects? Curr Opin Insect Sci. 2015;8:69-78.

13. Ghanim M. A review of the mechanisms and components that determine the transmission efficiency of tomato yellow leaf curl virus (Geminiviridae; Begomovirus) by its whitefly vector. Virus Res. 2014;186:47-54.

14. Gray S, Cilia M, Ghanim M. Circulative,"nonpropagative" virus transmission: an orchestra of virus-, insect-, and plant-derived instruments. Adv Virus Res. 2014;89:141-99.

15. Davis TS, Horton DR, Munyaneza JE, Landolt PJ. Experimental infection of plants with an herbivore-associated bacterial endosymbiont influences herbivore host selection behavior. PLoS One. 2016;7(11):e49330.

16. Chaudhary R, Atamian HS, Shen Z, Briggs SP, Kaloshian I. GroEL from the endosymbiont Buchnera aphidicola betrays the aphid by triggering plant defense. Proc Natl Acad Sci. 2014;111(24):8919-24.

17. Shi X, Gao Y, Yan S, Tang X, Zhou X, Zhang D, et al. Aphid performance changes with plant defense mediated by cucumber mosaic virus titer. Virol J. 2016;13(1):70.

18. Ingwell LL, Eigenbrode SD, Bosque-Perez NA. Plant viruses alter insect behavior to enhance their spread. Sci Rep. 2012;2:578.

19. Dietzgen RG, Mann KS, Johnson KN. Plant virus-insect vector interactions: current and potential future research directions. Viruses. 2016;8(11):303.

20. Wang R, Zhu-Salzman K, Elzaki M, Huang Q, Chen S, Ma Z, et al. Mikania micrantha wilt virus alters insect vector's host preference to enhance its own spread. Viruses. 2019;11(4):1.

21. Mauck K, Bosque-Pérez NA, Eigenbrode SD, Moraes CMD, Mescher MC. Transmission mechanisms shape pathogen effects on host-vector interactions: evidence from plant viruses. Funct Ecol. 2012;26(5):1162-75.

22. Carmo-Sousa M, Moreno A, Garzo E, Fereres A. A non-persistently transmitted-virus induces a pull-push strategy in its aphid vector to optimize transmission and spread. Virus Res. 2014;186:38-46.

23. Machado-Assefh CR, Lopez-Isasmendi G, Tjallingii WF, Jander G, Alvarez AE. Disrupting Buchnera aphidicola, the endosymbiotic bacteria of Myzus persicae, delays host plant acceptance. Arthropod Plant Interact. 2015;9(5): 529-41.

24. Gauthier JP, Outreman Y, Mieuzet L, Simon JC. Bacterial communities associated with host-adapted populations of pea aphids revealed by deep sequencing of 165 ribosomal DNA. PLoS One. 2015;10(3):e0120664.

25. Baldwin IT. The evolutionary context for herbivore-induced plant volatiles: beyond the 'cry for help'. Trends Plant Sci. 2010;15(3):167-75.

26. Chapman RF, Bernays EA, Simpson SJ. Attraction and repulsion of the aphid, Cavariella aegopodii, by plant odors. J Chem Ecol. 1981;7(5):881-8.

27. Hori M. Repellency of rosemary oil against Myzus persicae in a laboratory and in a screenhouse. J Chem Ecol. 1998;24(9):1425-32.

28. Joó É, Van Langenhove H, Šimpraga M, Steppe K, Amelynck C, Schoon N, et al. Variation in biogenic volatile organic compound emission pattern of Fagus sylvatica L. due to aphid infection. Atmos Environ. 2010;44(2):227-34

29. Hori M, Komatsu H. Repellency of rosemary oil and its components against the onion aphid, Neotoxoptera formosana (TAKAHASHI) (Homoptera, Aphididae). Appl Entomol Zool. 1997;32(2):303-10.

30. Chen G, Su Q, Shi X, Liu X, Peng Z, Zheng H, et al. Odor, not performance, dictates Bemisia tabaci's selection between healthy and virus infected plants. Front Physiol. 2017;8(8):1

31. Mauck KE, De Moraes CM, Mescher MC. Biochemical and physiological mechanisms underlying effects of cucumber mosaic virus on host-plant traits that mediate transmission by aphid vectors. Plant Cell Environ. 2014; 37(6):1427-39.

32. Jf VDH, Verbeek M. Endosymbiotic bacteria associated with circulative transmission of potato leafroll virus by Myzus persicae. J Gen Virol. 1994 75(Pt 10):2559-65.

33. Dáder $\mathrm{B}$, Fereres $\mathrm{A}$, Moreno A, Trębicki P. Elevated $\mathrm{CO}_{2}$ impacts bell pepper growth with consequences to Myzus persicae life history, feeding behaviour and virus transmission ability. Sci Rep. 2016;6(1):19120.
34. Zhang F, Li X, Zhang Y, Coates B, Zhou XJ, Cheng D. Bacterial symbionts, Buchnera, and starvation on wing dimorphism in English grain aphid, Sitobion avenae (F.) (Homoptera: Aphididae). Front Physiol. 2015;6:155.

35. White JA, Kelly SE, Perlman SJ, Hunter MS. Cytoplasmic incompatibility in the parasitic wasp Encarsia inaron: disentangling the roles of Cardinium and Wolbachia symbionts. Heredity. 2009;102(5):483.

36. Chung SH, Jing X, Luo Y, Douglas AE. Targeting symbiosis-related insect genes by RNAi in the pea aphid-Buchnera symbiosis. Insect Biochem Molec. 2018;95:55-63.

37. Oliver KM, Russell JA, Moran NA, Hunter MS. Facultative bacterial symbionts in aphids confer resistance to parasitic wasps. P Natl Acad Sci USA. 2003; 100(4):1803-7.

38. Livak KJ, Schmittgen TD. Analysis of relative gene expression data using real-time quantitative PCR and the $2{ }^{-{ }^{\Delta \Delta}}$ CT method. Methods. 2001;25(4): $402-8$

\section{Publisher's Note}

Springer Nature remains neutral with regard to jurisdictional claims in published maps and institutional affiliations.
Ready to submit your research? Choose BMC and benefit from:

- fast, convenient online submission

- thorough peer review by experienced researchers in your field

- rapid publication on acceptance

- support for research data, including large and complex data types

- gold Open Access which fosters wider collaboration and increased citations

- maximum visibility for your research: over $100 \mathrm{M}$ website views per year

At BMC, research is always in progress.

Learn more biomedcentral.com/submissions 